\title{
Chemical constituent analysis of the Babassu (Orbignya phalerata Mart.) mesocarp
}

\author{
Gabriela Batista de Farias ${ }^{1}$, Jean Lucas da Silva Rodrigues ${ }^{1}$, Maria Nilce de Sousa Ribeiro², \\ Lyege Oliveira Magalhães ${ }^{3}$, Antonio Gilberto Ferreira ${ }^{4}$, Maria da Paz Lima ${ }^{1, *}$
}

Edited by

Juan Carlos Salcedo-Reyes

(salcedo.juan@javeriana.edu.co)

1. Instituto Nacional de Pesquisas da

Amazônia, Coordenação de Tecnologia e

Inovação, Avenida André Araújo,

2936, CEP 69011-970, Manaus,

AM, Brasil.

2. Universidade Federal do Maranhão,

Centro de Ciências Biológicas e da

Saúde, Avenida dos Portugueses,

1966, CEP 65080805, São Luís,

MA, Brasil.

3. Instituto Federal de Educação,

Departamento Acadêmico de Quimica,

Ambiente e Alimentos, Avenida Sete

de Setembro, 1975, CEP 69020-120,

Manaus, AM, Brasil.

4. Universidade Federal de São Carlos,

Departamento de Química, Rodovia

Washington Luis, Km 235, CEP

13565-905, São Carlos, SP, Brasil.

*mdapaz@inpa.gov.br

Received: 16-04-2018

Accepted: 07-12-2018

Published on line: 22-07-2019

Citation: Batista de Farias G, da Silva Rodrigues JL, de Sousa Ribeiro MN,

Oliveira Magalhães L, Gilberto Ferreira

A, da Paz Lima M. Chemical constituent

analysis of the Babassu (Orbignya phalerata

Mart.) mesocarp, Universitas Scientiarum,

24 (2): 323-335, 2019.

doi: 10.11144/Javeriana.SC24-2.ccao

Funding:

Conselho Nacional de Desenvolvimento

Cientifico e Tecnologico (CNPq) and

Fundação de Amparo a Pesquisa do

Estado do Amazonas (FAPEAM).

Electronic supplementary material: N.A.

\begin{abstract}
The Babassu nut (Orbignya phalerata Mart.) mesocarp is traditionally transformed to flour and consumed in some Brazilian areas for its attributed medicinal activity; however, its chemical properties remain to be elucidated. The present work aimed at analyzing the babassu mesocarp phytochemical constituents. Babassu nut samples were collected in the Brazilian Amazon, and their mesocarps were prepared and macerated in different solvents. The chromatographic fractionation of selected methanol extracts yielded three fractions, A-5, A-6, and B-1 that were characterized with high resolution methods. Fraction A-5 was characterized through GC/MS as a fatty acid mixture with predominance of eicosanoic (38.67\%) and 11-octadecanoic $(21.71 \%)$ acids. Fraction A-6 was characterized by the presence of three phytosteroids (32.02\%), sesquiterpene (nerolidol; 24.89\%), and diterpene (17-acetoxy-19-kauranal; $15.17 \%$ ). The ${ }^{1} \mathrm{H}$ and ${ }^{13} \mathrm{C}$ NMR spectra on fraction A-6 showed characteristic chemical shifts for its compounds. Compound B-1 was identified as ergostanol-3-benzoate based on NMR experiments in one and two dimensions. These results constitute the first identification of babassu mesocarp chemical constituents in 1 and 2-dimensions, paving the way to understanding its role in popular medicine.
\end{abstract}

Keywords: arecaceae; fatty acids; GC/MS; NMR; phytosteroids; terpenes.

\section{Introduction}

The Babassu palm tree, Orbignya phalerata Mart. (Arecaceae), is widely distributed in the Brazilian northern, northeastern, and mid-western regions. Babassu occurrence is particularly concentrated in the region known as "Mata dos Cocais", which entails the States of Maranhão, Tocantins, and Piauí [1]. In the State of Amazonas, babassu palm trees occur in non-flooded landscapes [2, 3]. This species has several scientific synonyms: Attalea lydiae 
(Drude) Barb. Rodr., Attalea speciosa Mart. Orbignya barbosiana Burret, Orbignya martiana Barb. Rodr., and Orbignya speciosa (Mart. Ex Spreng.) Barb. Rodr. [2, 4].

The babassu nut mesocarp is a food source, has medicinal applications in popular culture, and its oil is employed in biodiesel production [5-7]. Despite being one of the most economically important fruits in Brazil, the babassu nut composition and its nutritional and medicinal values remain little investigated. The babassu nut mesocarp is predominantly amylaceous (ca. 66\%), containing calcium, phosphorus, magnesium, potassium, and iron [1]. The flour obtained from the babassu mesocarp-after its drying, grinding, and roasting-is consumed as garnish in traditional dishes or drunk dissolved in water to treat rheumatism, ulcers, and inflammations $[8,9]$. Furthermore, immunomodulatory, anti-inflammatory, and antithrombotic activities have been reported [8, 10-12]. This work presents the very first report on the phytochemical composition of the Amazonian babassu mesocarp.

\section{Materials and methods}

\section{Babassu nut samples and extract preparation}

Two babassu nut samples were obtained in natura from the Nossa Senhora Aparecida Community in the city of Rio Preto da Eva in the Brazilian State of Amazonas. The nuts were rinsed, dried at room temperature, and manually peeled with the help of a knife to remove their mesocarps (initial weight the mesocarps: $1818 \mathrm{~g}$ ). Mesocarp extracts were prepared as follows:

Mesocarp sample A $(880 \mathrm{~g})$ was subjected to maceration with methanol at room temperature for seven days, followed by maceration with water in a refrigerated environment for five days. This protocol resulted in one methanolic extract (Extract 1) and one aqueous extract (Extract 2).

Mesocarp sample B (938 g) was subjected to successive macerations with hexane, methanol, and water for seven days in each solvent, yielding one hexane extract (Extract 3), one methanol extract (Extract 4), and one aqueous extract (Extract 5).

All organic extracts were concentrated using a rotary evaporator, and the aqueous extracts were obtained after being lyophilized. All five extracts were subjected to thin layer chromatographic separation. From this step, promising extracts (as informed by thin layer chromatography analyses) were selected for chromatographic fractioning. 


\section{Chromatographic fractionation of methanolic extract 1}

The methanolic extract $1(6.11 \mathrm{~g})$ was subjected to chromatographic fractionation on a silica gel column $(70-230 \mathrm{mesh} ; \mathrm{h} \times \varphi=24.0 \times 5.0 \mathrm{~cm})$ and eluted with hexane, hexane: EtOAc (2 - $50 \%$ ), EtOAc, and MeOH. Out of the resulting 23 fractions, the combined fractions 11 and 12 were subjected to another chromatographic fractionation on silica gel (230-400 mesh; $\mathrm{h} \times \varphi=$ $32.0 \times 1.5 \mathrm{~cm})$ and eluted with hexane and hexane: EtOAc (10-50\%). In parallel, fractions 5 (henceforth labelled as A - 5) and 6 (henceforth labelled as A - 6) were analyzed by GC/MS and ${ }^{1} \mathrm{H}$ and ${ }^{13} \mathrm{C}$ NMR.

\section{Liquid-liquid partition of extract 4}

The methanolic extract 4 (18.94 g) was successively partitioned with hexane, dichloromethane, ethyl acetate, and methanol. The hydroalcoholic phase was fractionated on a XAD-2 chromatography column (h x $\varphi=20 \times 3.8 \mathrm{~cm}$ ) and eluted with $\mathrm{MeOH}: \mathrm{H}_{2} \mathrm{O}: \mathrm{HOAc}(50: 45: 5), \mathrm{H}_{2} \mathrm{O}$ : formic acid (95:5), $\mathrm{H}_{2} \mathrm{O}$, $\mathrm{MeOH}, \mathrm{CH}_{2} \mathrm{Cl}_{2}$, and EtOAc. Out of the nine fractions yielded, fraction 7 was eluted with $\mathrm{CH}_{2} \mathrm{Cl}_{2}$, fractionated on a silica gel column (70-230 mesh; hex $\times 30 \times 3.0 \mathrm{~cm})$, and eluted with hexane and hexane: EtOAc $(2-50 \%)$ to yield compound B-1.

\section{Chemical analysis procedures}

Nuclear Magnetic Resonance (NMR) spectra were measured in a Bruker DRX 400 apparatus; chemical shifts $(\delta)$ were expressed in ppm and coupling constants $(J)$ in Hertz; TMS was used as internal standard. The Gas Chromatography/Mass Spectroscopy (GC/MS) run was conducted with a Shimadzu A-17 system, equipped with a DB-5 $(30 \mathrm{~m} \times 0.25 \mathrm{~mm} \times$ $0.25 \mu \mathrm{m}$ ) fused silica capillary column; the heating scheme used consisted of $60{ }^{\circ} \mathrm{C}-210{ }^{\circ} \mathrm{C}, 10{ }^{\circ} \mathrm{C} / \mathrm{min} ; 210^{\circ} \mathrm{C}-280{ }^{\circ} \mathrm{C}, 10{ }^{\circ} \mathrm{C} / \mathrm{min}$, remaining for $10 \mathrm{~min}$. Column chromatography (CC) was performed on silica gel 60 (Merck, 70-230 mesh), Amberlit (XAD-2, Supelco). Analytical Thin-layer Chromatography (TLC) was carried out on Merck Kiesegel 60 F254 plates $(0.25 \mathrm{~mm})$.

\section{Results and Discussion}

A total of five babassu nut extracts were obtained from macerations with methanol (Extract 1; $21.26 \mathrm{~g}$ and Extract 4; $22.25 \mathrm{~g}$ ), hexane (Extract 3; $0.17 \mathrm{~g}$ ), and water (Extract 2; $11.49 \mathrm{~g}$ and Extract $5 ; 3.54 \mathrm{~g}$ ). Two of the methanol extracts (Extracts 1 and 4 ) were selected, fractionated, and partitioned. Out of extract 1, fractions A-5 and A-6 were selected and analyzed through GC/MS and NMR, whereas extract 4 was further characterized with NMR experiments in one and two-dimensions. 


\section{Fatty acid composition of fraction A-5}

Fraction A-5 $(2.0 \mathrm{mg})$ from extract 1 had its chemical composition characterized through GC/MS. This fraction is rich in fatty acids identified as methyl esters, containing $47.80 \%$ of saturated and $40.75 \%$ of mono unsaturated fatty acids (Table 1). Eicosanoic, or arachidic acid, (C20:0 $38.67 \%$ ) and 11-octadecenoic acid (C18:1 21.71\%) were also present in this fraction. The characteristic signals of the fatty acids in Fraction A-5, as revealed by ${ }^{1} \mathrm{H}$ and ${ }^{13} \mathrm{C}-\mathrm{NMR}$ spectra, are presented in Table 2. The ${ }^{1} \mathrm{H}$ NMR spectrum revealed signals of double bonded hydrogens ( $\delta$ 5.39-5.33), hydrogens adjacent to the carbonyl group ( $\delta$ 2.32-2.30), and methyl groups ( $\delta 0.86-0.83$ ); whereas the ${ }^{13} \mathrm{C}$ NMR spectrum exhibited typical acid carbonyl chemical shifts in the range of $\delta 175.83$ to 174.68 and olefinic carbons shifts between $\delta 132.33$ and 129.35 .

Previous studies on babassu nut fatty acids from the Maranhão region revealed the predominance (44.9-54.7\%) of short chain saturated fatty acids, such as lauric acid (C12:0) $[13,14]$. Ours is the first report on babassu mesocarp fatty acids analysis revealing predominance of saturated (C20:0) and unsaturated (C18:1) fatty acids. There are registers of these predominant fatty acids in fruits of some botanical families; for instance, eicosanoic acid was found in high concentrations (26.0-33.3\%) in Sapindaceae fruits [15], and the 11Z-octadecenoic acid (cis-vaccenic acid) is a common (1.9-95.1\%) octadecenoic acid among pulp lipids in fruits from other families [16]. Octadecenoic acid has been detected at low proportions (2.0-2.4\%) in the mesocarp of some species of the Arecaceae [17]. Palm fruits are one of the main sources of oils and fats, but few studies have focused on their chemical composition.

\section{Chemical composition of fraction A-6}

The GC/MS analyses of fraction A-6 (5.0 mg), from extract 1, revealed the presence of steroids (32.0\%), sesquiterpene (24.9\%) and diterpene (15.2\%), these major constituents of fraction A-6 are presented in Table 3 and their structural formulae in Fig. 1. The ${ }^{1} \mathrm{H}$ NMR spectrum for this fraction exhibited signs of olefinic hydrogens between regions of $\delta$ 5.39-5.32 and 5.11-5.09; carbinolic hydrogens at $\delta$ 4.34-4.28, 4.19-4.12 and 3.29-3.18, and methyl groups at $\delta$ 0.96-0.81. The ${ }^{13} \mathrm{C}$ NMR spectrum showed signals of methyl groups at region $\delta 29.59-15.54$ as well as signals of olefinic double bonds compatible with ergostane 7, 22-diene 3-ol ( $\delta$ 137.0, 115.7, 135.2 and 129.3) and $\beta$-sitosterol ( $\delta 139.0$ and 121.5). This spectrum also showed the olefinic double for nerolidol sesquiterpene $(\delta 145.79,135.16,131.47$, $125.60,125.45$ and 111.62). The carbinolic carbons were found between $\delta$ 80.30-71.00 and carbonyls of diterpene at $\delta 194.01$ and 173.23. 
Table 1. Fatty acid composition (\%) of babassu extract fraction A-5 after its chemical derivatization.

\begin{tabular}{llll}
\hline \multicolumn{1}{c}{ Compounds } & \multicolumn{1}{c}{$\begin{array}{c}\text { Formula } \\
(\mathbf{M} / \mathbf{Z})\end{array}$} & RT / MIN & \% \\
\hline nonanoic acid, 9-oxo-, methyl ester & $\mathrm{C}_{10} \mathrm{H}_{18} \mathrm{O}_{3}(186)$ & 12.37 & 2.85 \\
\hline 9-hexadecenoic acid (Z)-, methyl ester & $\mathrm{C}_{17} \mathrm{H}_{32} \mathrm{O}_{2}(288)$ & 16.63 & 1.63 \\
\hline eicosanoic acid, methyl ester & $\mathrm{C}_{21} \mathrm{H}_{42} \mathrm{O}_{2}(326)$ & 17.94 & 38.67 \\
\hline 14 methyl pentadecanoic acid, methyl ester & $\mathrm{C}_{17} \mathrm{H}_{34} \mathrm{O}_{2}(270)$ & 18.38 & 3.57 \\
\hline 11-octadecenoic acid, methyl ester & $\mathrm{C}_{19} \mathrm{H}_{36} \mathrm{O}_{2}(296)$ & 20.61 & 21.73 \\
\hline Octadecenoic acid, methyl ester & $\mathrm{C}_{19} \mathrm{H}_{38} \mathrm{O}_{2}(298)$ & 20.74 & 4.55 \\
\hline 9-octadecenoic acid(E)-, methyl ester & $\mathrm{C}_{19} \mathrm{H}_{36} \mathrm{O}_{2}(296)$ & 21.02 & 2.59 \\
\hline 11, 14- eicosadienoic acid, methyl ester & $\mathrm{C}_{21} \mathrm{H}_{38} \mathrm{O}_{2}(322)$ & 21.57 & 1.75 \\
\hline 9-octadecenoic acid, methyl ester & $\mathrm{C}_{10} \mathrm{H}_{36} \mathrm{O}_{2}(296)$ & 26.12 & 3.23 \\
\hline 11-undecenoic acid, methyl ester & $\mathrm{C}_{12} \mathrm{H}_{22} \mathrm{O}_{2}(198)$ & 29.23 & 5.27 \\
\hline tetracosanoic acid, methyl ester & $\mathrm{C}_{25} \mathrm{H}_{50} \mathrm{O}_{2}(382)$ & 30.88 & 2.71 \\
\hline
\end{tabular}

$\mathrm{HO}$

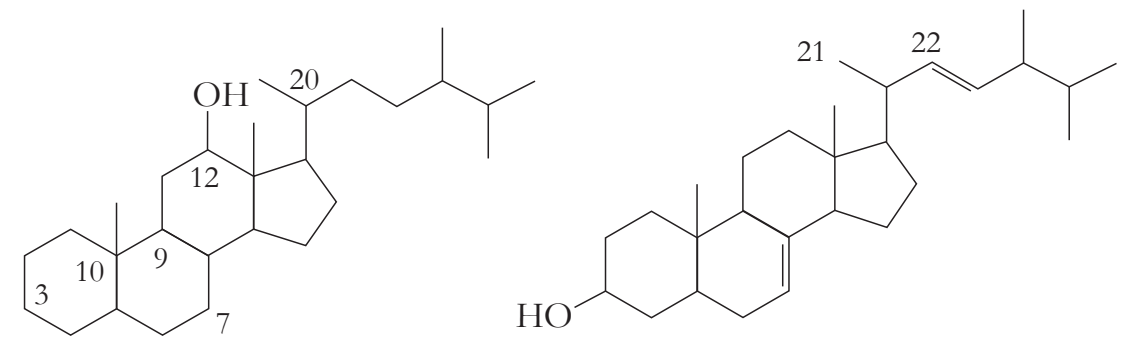

Ergostane-3, 12-diol

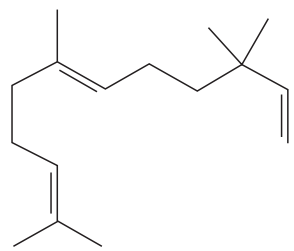

Nerolidol
Ergostane-7, 22-diene-3-ol

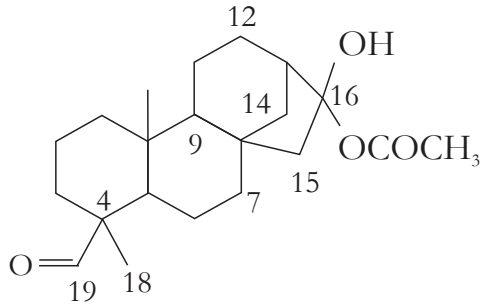

17-acetoxy-19-Kauranal

Figure 1. Chemical structures of the predominant constituents of fraction A-6. 
Table 2. Chemical shifts $(\delta)$ in the ${ }^{1} \mathrm{H}$ and ${ }^{13} \mathrm{C}-\mathrm{NMR}$ spectra of babassu extract fraction A-5.

\begin{tabular}{ccl}
\hline $\mathbf{R M N}^{1} \mathbf{H}$ & \multicolumn{1}{c}{$\mathbf{R M N}^{13} \mathbf{C}$} & Functional groups \\
$\left(\mathrm{CDCl}_{3}, 400 \mathrm{MHz}\right)$ & $\left(\mathrm{CDCl}_{3}, 100 \mathrm{MHz}\right)$ & \\
\hline & $175.83-174.68$ & $\mathrm{CO}$ \\
\hline $5.39-5.33$ & $132.33-129.35$ & $-\mathrm{CH}=\mathrm{CH}-$ \\
\hline $2.05-1.69$ & $26.41-24.14$ & $\mathrm{CH}_{2}-\mathrm{CH}=\mathrm{CH}-$ \\
\hline $2.32-2.30$ & $33.41-33.31$ & $\mathrm{CH}_{3} \mathrm{OCOCH}_{2}-$ \\
\hline $1.55-1.22$ & $30.54-28.61$ & $-\left(\mathrm{CH}_{2}\right) \mathrm{n}-$ \\
\hline $0.86-0.83$ & $15.56-15.45$ & $-\mathrm{CH}_{3}$ \\
\hline
\end{tabular}

Identification of compound B-1

Compound B-1 $(3.0 \mathrm{mg})$, from extract 1, was characterized as an ergostane-type steroid (Fig. 2) based on one-dimensional $\left({ }^{1} \mathrm{H}\right.$ and ${ }^{13} \mathrm{C}$ ), and two-dimensional (HSQC and HMBC) NMR spectra. The ${ }^{1} \mathrm{H}$ NMR spectrum showed signs of methyl groups typical of ergostane-type steroids defined by two singlets at $\delta 0.86$ (Me-18) and 0.89 (Me-19), and four doublets

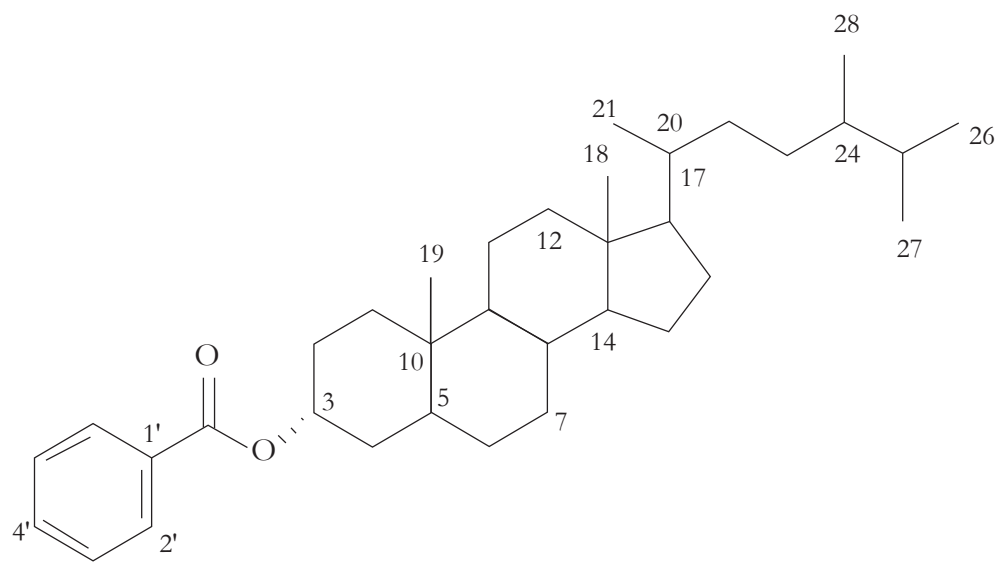

Figure 2. Chemical structure of compound B-1. 
Table 3. Major chemical constituents (\%) of the fraction A-6.

\begin{tabular}{lccc}
\hline \multicolumn{1}{c}{ Compounds } & $\begin{array}{c}\text { Formula } \\
(\mathbf{M} / \mathbf{Z})\end{array}$ & RT/ MIN & \% \\
\hline ergostane-3, 12-diol & $\mathrm{C}_{28} \mathrm{H}_{50} \mathrm{O}(418)$ & 45.24 & 13.47 \\
\hline ergosta-7, 22-dien-3-ol & $\mathrm{C}_{28} \mathrm{H}_{46} \mathrm{O}(398)$ & 46.68 & 13.86 \\
\hline 3-sitosterol & $\mathrm{C}_{29} \mathrm{H}_{50} \mathrm{O}(414)$ & 47.05 & 4.69 \\
\hline 3, 7, 11-trimethyl, 1, 6, 10-dodecatrien-3-ol (nerolidol) & $\mathrm{C}_{15} \mathrm{H}_{26} \mathrm{O}(222)$ & 50.53 & 24.89 \\
\hline 17-acetoxy-19-kauranal & $\mathrm{C}_{22} \mathrm{H}_{34} \mathrm{O}_{3}(346)$ & 52.89 & 15.17 \\
\hline
\end{tabular}

at $J=6.5 \mathrm{~Hz}$ at $\delta 0.82$ (Me-21), 0.88 (Me-26 andMe-28), and 0.92 (Me-27). The oxymethyl hydrogen signal was verified at $\delta 4.33(\mathrm{~m})$. The ${ }^{13} \mathrm{C}$ NMR spectrum showed steroid signals at the $\delta$ 56.90-11.42 region, as well as signals of aromatic carbons in $\delta 132.29$ (C-1'), 130.92 (C-4'), 130.49 (C-3' and C-5'), and $128.82\left(\mathrm{C}-2^{\prime}\right.$ and $\left.\mathrm{C}-6^{\prime}\right)$. The carbon signal at $\delta 167.71$ indicated carbonyl of the benzoyl ester group linked at C-3 $(\delta 66.20)$ with axial arrangement. The HMBC experiment showed oxymetinic hydrogen correlations $(\delta 4.33)$ with carbon signals at $\delta 167.71(\mathrm{C}=\mathrm{O}), 132.20\left(\mathrm{C}-4^{\prime}\right)$, and $130.92\left(\mathrm{C}-3^{\prime}\right.$ and $\left.\mathrm{C}-5^{\prime}\right)$. These lines of evidence led to identifying compound B-1 as ergostanol-3-benzoate. This compound is reported for the first time in Arecaceae nuts. Steroid of the ergostane and stigmastane types [18] were previously found in Areca catechu (Arecaceae) fruits. Silva et al. [19] identified several foods, including oleaginous plants, that are natural phytosteroid sources and exhibit hypocholesterolemic properties, potentially helping to prevent cardiovascular diseases.

\section{Conclusion}

In this work we have deepened the current understanding of the babassu mesocarp composition via high-resolution chemical analysis methods. We have revealed the presence of fatty acids, steroids, sesquiterpene, and diterpene in the babassu nut, adding information that is valuable to explaining the economic importance of this palm tree Brazil. However, further knowledge on the babassu nut mesocarp constituent molecules is still required to better understand the nut's dietary value and to justify its use in popular medicine. 


\section{Acknowledgments}

The authors thank the Brazilian Agencies: Conselho Nacional de Desenvolvimento Cientifico e Tecnologico (CNPq) and Fundação de Amparo a Pesquisa do Estado do Amazonas (FAPEAM) for their financial support.

\section{Conflict of interest}

The authors have no conflict of interest to declare.

\section{References}

[1] Carrazza LR, Avila JCC, Silva ML. Manual tecnológico de aproveitamento integral do fruto e da folha do babaçu (Attalea ssp.). 2 a ed.- Instituto Sociedade, População e Natureza. Brasilia, Brasil 2012.

[2] Cavallari MM, Toledo MM. What is the name of the babassu? A note on the confusing use of scientific names for this important palm tree. Rodriguésia 67: 533-538, 2016.

doi: 10.1590/2175-7860201667218

[3] Miranda IPA, Rabelo A, Bueno CR, Barbosa EM, Ribeiro MNS. Frutos de palmeiras da Amazônia. Ed.-INPA, Manaus, Brasil, 2001.

[4] http://www.tropicos.org/Name/2400600. Accessed on 02/03/2018.

[5] Prance GT, Balee W, Boom BM, Carneiro RC. Quantitative ethnobotany and case for conservation in Amazonia, Conservative Biology, 1: 296-310, 1987.

doi: 10.1111/j.1523-1739.1987.tb00050.x

[6] Rocha DQ, Barros DK, Costa EJC, Souza SS, Passos RR, VeigaJunior VF, Chaar JS. Determinação da matéria-prima utilizada na produção do biodiesel adicionado ao diesel mineral a través de monitoramento seletivo de íons, Quimica Nova, 31: 1062-1066, 2008.

doi: 10.1590/S0100-40422008000500022

[7] Ranucci CR, Alves, HJ, Monteiro, MR, Kugelmeier CL, Bariccatti RA, Rodrigues OC, Antônio SE. Potential alternative aviation fuel from jatropha (Jatropha curcas L.), babassu (Orbignya phalerata) and palm kernel (Elaeis guineensis) as blends with Jet-A1 kerosene, Journal of Cleaner Production, 185: 860-870, 2018.

doi: 10.1016/j.jclepro.2018.03.084 
[8] Silva BP, Parente JP. An anti-inflammatory and immunomodulatory polysaccharide from Orbignya phalerata, Fitoterapia, 72: 887-893, 2001.

doi: 10.1016/S0367-326X(01)00338-0

[9] Mércia HSL, Souza CA, Monteiro PM. Ethnopharmacological use of babaçu (Orbignya phalerata Mart) in communities of babassu nut breakers in Maranhão, Brazil, Journal of Ethnopharmacology, 133:1-5, 2011.

doi: 10.1016/j.jep.2010.08.056

[10] Barroqueiro ESB, Prado DS, Barcellos PS, Silva TA, Pereira WS, Silva LA, Maciel MCG, Barroqueiro RB, Nascimento FRF, Goncalves AG, Guerra RNM. Immunomodulatory and antimicrobial activity of babassu mesocarp improves the survival in lethal sepsis, Evidence-Based Complementary and Alternative Medicine, 7p, 2016.

doi: $10.1155 / 2016 / 2859652$

[11] Silva MCP, Brito JM, Ferreira AS, Vale AAM, Santos APA,Silva LA, Pereira PVS, Nascimento FRF, Nicolete R, Guerra RNM. Antileishmanial and immunomodulatory effect of babassuloaded PLGA microparticles: A useful drug target to Leishmania amazonensis infection, Evidence-based Complementary and Alternative Medicine, 14p, 2018.

doi: $10.1155 / 2018 / 3161045$

[12] Azevedo APS, Farias JC, Costa GC, Ferreira SCP, Aragão-Filho WC, Sousa PRA, Pinheiro MT, Maciel MCG, Silva LA, Lopes AS, Barroqueiro ESB, Borges MOR, Guerra RNM, Nascimento FRF. Antithrombotic effect of chronic oral treatment with Orbignya phalerata Mart, Journal of Ethnopharmacology, 111: 155-159, 2007.

doi: 10.1016/j.jep.2006.11.005

[13] Santos DS, Silva IG, Araújo BQ, Lopes-Júnior CA, Monção NBN, Cito AMGL, Souza MHSL, Nascimento MDSB, Costa MCP. Extraction and evaluation of fatty acid compositon of Orbignya phalerata Martius (Arecaceae) from Maranhão State, Brazil, Journal of the Brazilian Chemical Society, 24: 355-362, 2013.

doi: 10.5935/0103-5053.20130045

[14] Ferreira BS, Faza LP, Mireille Le Hyaric M. A comparison of the physicochemical properties and fatty acid composition of indaia (Attalea dubia) and babassu (Orbignya phalerata) oils 4p, 2012.

doi: $10.1100 / 2012 / 532374$ 
[15] Chai KF, Adzahan NM, Karim R, Rukayadi Y, Ghazali HM. Characteristics of fat, and saponin and tannin contents of 11 varieties of rambutan (Nephelium lappaceum L.) seed, International Journal of Food Properties, 21: 1091-1106, 2018.

doi: 10.1080/10942912.2018.1479857

[16] Shibahara A, Yamamoto K, Nakayama T, Kajimoto G. cisVaccenic acid in pulp lipids of commonly available fruits, Journal of the American Oil Chemists' Society, 64: 397-401, 1987.

doi: 10.1007/BF02549303

[17] Montúfar R, Laffargue A, Pintaud JC, Hamon S, Avallone S, Dussert S. Oenocarpus batana Mart. (Arecaceae): rediscovering a source of high oleic vegetable oil from Amazonia, The Journal of the American Oil Chemists' Society, 87:167-172, 2010.

doi: 10.1007/s11746-009-1490-4

[18] Yang WQ, Wang HC, Wang WJ, Wang Y, Zhang XQ, Ye WC. Chemical constituents from the fruits of Areca catechu, Journal of Chinese Medical Materials, 35: 400-402, 2012.

[19] Silva P, Pinheiro AC, Rodriguez L, Figueroa V, Baginsky C. Fuentes naturales de fitoesteroles y factores de produccion que lo modifican, Archivos Latinoamericanos de Nutrición, 66: 17-24, 2016. 


\section{Análisis de constituyentes químicos del mesocarpo del Babasú (Orbignya phalerata Mart.)}

Resumen: El mesocarpo de la nuez del babasú (Orbignya phalerata Mart.) se transforma tradicionalmente en harina y se consume en algunas zonas de Brasil por la actividad medicinal que se le atribuye; sin embargo, sus propiedades químicas aún no han sido dilucidadas. El presente trabajo busca analizar los constituyentes fitoquímicos del mesocarpo del babasú. Se colectaron muestras de nueces de babasú en la Amazonia brasileña y sus mesocarpos se prepararon y maceraron en distintos solventes. El fraccionamiento cromatográfico de extractos de metanol seleccionados produjo tres fracciones (A-5, A-6 y B-1) que se caracterizaron con métodos de alta resolución. La fracción A-5 se caracterizó a través de CG/EM como una mezcla de ácidos grasos con predominancia de los ácidos eicosanoico (38.67\%) y 11 -octadecanoico $(21.71 \%)$. La fracción A-6 se caracterizó por la presencia de tres fitoesteroides $(32.02 \%$ ) sesquiterpeno (nerolidol; $24.89 \%$ ) y diterpeno (17-acetoxi-19-kauranal; $15.17 \%$ ). Los espectros de ${ }^{1} \mathrm{H}$ y ${ }^{13} \mathrm{C}$ de la RMN en la fracción A-6 mostraron desplazamientos químicos característicos para sus componentes. Con base en los experimentos de RMN en una y dos dimensiones, el compuesto B-1 fue identificado como ergostanol3-benzoato. Estos resultados constituyen la primera identificación de los constituyentes químicos del mesocarpo del babasú en una y dos dimensiones, lo cual allana el camino para el entendimiento de su papel en la medicina popular.

Palabras clave: arecaceae; ácidos grasos; cromatografía de gases/ espectrometría de masas; resonancia magnética nuclear; fitoesteroides; terpenos. 


\section{Análise dos constituintes químicos do Mesocarpo de Babaçu (Orbignya phalerata Mart.)}

Resumo: O mesocarpo do coco de Babaçu (Orbignya phalerata Mart.) é tradicionalmente transformado em farinha e consumido em algumas áreas do Brasil pela sua suposta atividade medicinal; no entanto, suas propriedades químicas ainda não foram elucidadas. O presente trabalho buscou analisar os constituintes fitoquímicos do coco de Babaçu. Amostras de coco de Babaçu foram coletadas na Amazônia brasileira, e seus mesocarpos foram preparados e macerados em diferentes solventes. O fracionamento cromatográfico dos extratos de metanol selecionados gerou três frações (A-5, A-6 e B-1) que foram caracterizadas com métodos de alta resolução. A fração A-5 foi caracterizada mediante CG/EM como uma mistura de ácidos graxos com predominância dos ácidos eicosanóico (38.67\%) e 11-octadecanóico (21.71\%). A fração A-6 se caracterizou pela presença de três fitoesteróis (32.02\%), sesquiterpeno (nerolidol; $24.89 \%$ ) e diterpeno (17-acetoxy-19-kauranal; $15.17 \%$ ). Os espectros de ${ }^{1} \mathrm{H} \mathrm{e}{ }^{13} \mathrm{C}$ da NMR na fração A-6 mostraram deslocamentos químicos característicos dos seus componentes. O componente B-1 foi identificado como ergostanol-3-benzoato segundo os experimentos de RMN em uma e duas dimensões. Estes resultados constituem a primeira identificação dos constituintes químicos do mesocarpo de Babaçu em 1 e 2 dimensões, o que pavimenta o caminho para entender seu papel na medicina tradicional.

Palavras-chave: arecaceae; ácidos graxos; cromatografia de gases/ espectometria de masas; ressonância magnética nuclear; fitoesteróis; terpenos. 


\section{Gabriela Batista de Farias and Jean Lucas da Silva Rodrigues}

Undergraduate Chemistry students at Universidade Federal do Amazonas.

\section{Maria Nilce de Sousa Ribeiro}

Pharmaceutical, Doctor in Organic Chemistry (Universidade de São Paulo). Professor at the Universidade Federal do Maranhão.

\section{Lyege Oliveira Magalhães}

Chemistry, Doctor in Science (Universidade Federal de São Carlos). Professor at the Instituto Federal de Educação.

\section{Antonio Gilberto Ferreira}

Chemistry, Post-doctorate in Nuclear Magnetic Resonance (University of Sheffield-Inglerra). Professor at the Universidade Federal de São Carlos.

\section{Maria da Paz Lima}

Chemistry, Doctor in Science (Universidade Federal de São Carlos). Researcher of Natural Products Chemistry Laboratory at the Instituto Nacional de Pesquisas da Amazônia. 